\title{
The effects of thermal acclimation on lethal temperatures and critical thermal limits in the green vegetable bug, Nezara viridula (L.) (Hemiptera: Pentatomidae)
}

\author{
Pol Chanthy ${ }^{1,2}$, Robert J. Martin ${ }^{3,4}$, Robin V. Gunning ${ }^{5}$ and Nigel R. Andrew ${ }^{1 *}$ \\ ' Centre for Behavioural and Physiological Ecology, Department of Zoology, School of Environmental and Rural Sciences, Faculty of Arts and Sciences, \\ University of New England, Armidale, NSW, Australia \\ ${ }^{2}$ Cambodian Agricultural Research and Development Institute, Phnom Penh, Cambodia \\ ${ }^{3}$ Agricultural Systems Research Cambodia Co. Ltd., Battambang, Cambodia \\ ${ }^{4}$ Maddox Jolie-Pitt Foundation, Rotanak Commune, Battambang, Cambodia \\ ${ }^{5}$ NSW Department of Primary Industries, Tamworth Agricultural Institute, Calala, NSW, Australia
}

\section{Edited by:}

Audrey Dussutour, Centre National de la Recherche Scientifique, France

\section{Reviewed by:}

Ulrich Theopold, Stockholm

University, Sweden

David Rivers, Loyola University

Maryland, USA

*Correspondence:

Nigel R. Andrew, Centre for

Behavioural and Physiological

Ecology, Department of Zoology,

School of Environmental and Rural

Sciences, Faculty of Arts and

Sciences, University of

New England, Armidale, NSW 2351,

Australia.

e-mail:nandrew@une.edu.au
According to geographical distribution, Nezara viridula (Heteroptera: Pentatomidae) can be found across tropical, subtropical, and temperate regions and this pattern is assumed to reflect differences in thermal adaptation, particularly in cold tolerance. Here the lethal temperature (LT) and critical thermal limits (CTL) (thermal tolerance) are examined for $N$. viridula. The upper LT for N. viridula at two contrasting climate locations (Breeza and Grafton, New South Wales, Australia) was $40.3^{\circ} \mathrm{C}$ with $20 \%$ survival under the stress of high temperature. The lower LT did not differ between these two populations and was $-8.0^{\circ} \mathrm{C}$ with $20 \%$ survival under low temperature stress. Survival of N. viridula increased after acclimation at high temperature for 7 days. In contrast, when acclimated at lower temperatures $\left(10\right.$ and $\left.15^{\circ} \mathrm{C}\right)$, survival of Breeza and Grafton N. viridula was lower than $20 \%$ at $-8.0^{\circ} \mathrm{C}$. Control-reared $N$. viridula adults $\left(25^{\circ} \mathrm{C}\right)$ had a mean $\mathrm{CT}_{\text {MinOnset }}$ (cold stupor) of $1.3 \pm 2.1^{\circ} \mathrm{C}$ and a mean $\mathrm{CT}_{\text {Max }}$ (heat coma) of $45.9 \pm 0.9^{\circ} \mathrm{C}$. After 7 days of acclimation at $10,20,30$, or $35^{\circ} \mathrm{C}, \mathrm{N}$. viridula adults exhibited a $1^{\circ} \mathrm{C}$ change in $\mathrm{CT}_{\text {Max }}$ and a $\sim 1.5^{\circ} \mathrm{C}$ change in $\mathrm{CT}_{\text {MinOnset. }} \mathrm{CT}_{\text {Max }}$ and $\mathrm{CT}_{\text {MinOnset }}$ of Breeza and Grafton N. viridula populations did not differ across acclimation temperatures. These results suggest that short-term temperature acclimation is more important than provenance for determining LTs and CTL in N. viridula.

Keywords: Nezara viridula, thermal tolerance, lethal temperature, critical thermal limits, acclimation temperature

\section{INTRODUCTION}

The relationships between potentially lethal environmental temperatures and survival of animals have long fascinated physiologists. Ecologically relevant measures of tolerance to potentially lethal temperatures (LT) have been recently reviewed by Terblanche et al. (2011). Ways in which these relationships are modified through time and space has also attracted study (Chen et al., 1990; Watson and Hoffmann, 1996; Terblanche et al., 2005a,b). Despite much focus on species responses to environmental variation through space and time, many taxa and geographic areas remain poorly studied (Terblanche et al., 2005b). Insect responses to high and low temperature are usually decoupled: lower LT limits typically respond more strongly to acclimation and natural selection than upper lethal limits, and it appears that phenotype can account for much of the response shown by insects (Klok and Chown, 2003; Ayrinhac et al., 2004; Hoffmann et al., 2005). Several studies, however, have shown that decoupling of upper and lower lethal limits is not typical of all insect species and as most investigations are undertaken using model species, this leaves several groups and geographic regions under-represented (Chown et al., 2002; Klok and Chown, 2003). Insects can increase resistance to cold stress when exposed to non-LT conditions prior to the cold stress being applied; these plastic responses are normally described only in terms of immediate effects on mortality (Rako and Hoffmann, 2006). Traditionally, studies of cold tolerance in insects have focused on seasonal adaptations related to overwintering observed after weeks or months of exposure to low temperature. In contrast, an extremely rapid cold-hardening response was observed in non-overwintering stages of insects and conferred protection against injury due to cold shock at temperatures above the supercooling point (SCP) (Lee et al., 1987). In studies of insect cold-hardiness, the SCP is defined as the temperature at which spontaneous nucleation of body fluids occurs (Salt, 1961; Zachariassen, 1985; Czajka and Lee, 1990; Carrillo et al., 2005).

For terrestrial insects, temperature has long been recognized as a major environmental factor responsible for species abundance and geographical distribution. Ambient temperature varies according to daylength and season, so that natural populations are often exposed to heat or cold stress (Gibbs et al., 2003). The capacity to adapt to and tolerate such stresses is extremely important for the persistence of populations (Klok and Chown, 2003; Ayrinhac et al., 2004). In temperate regions, species must tolerate cold conditions during winter and have developed a diversity of adaptive mechanisms to do so, including the occurrence of 
diapause and the production of antifreeze compounds (Graham et al., 2000; Ayrinhac et al., 2004).

Nezara viridula (L.) (Heteroptera: Pentatomidae) is widely distributed across the tropical, subtropical and temperate regions of Eurasia, Africa, Australia, and the Americas (Yukawa and Kiritani, 1965; Yukawa et al., 2007). This distribution pattern is apparently responding rapidly to climate warming (Musolin and Numata, 2003a,b; Musolin et al., 2004, 2007; Kiritani, 2006, 2007; Yukawa et al., 2007), and is especially assumed to be reflected in differences in thermal adaptation, and cold tolerance.

The aim of this paper is to determine for N. viridula: (1) whether the LT of populations differs between the two different climatic locations; (2) whether acclimation increases or decreases survival LT; and (3) the effect of acclimation on the critical thermal limits (CTL).

\section{MATERIALS AND METHODS STUDY SITE, COLLECTION, AND MAINTENANCE}

Samples of the polyphagous green vegetable bug (GVB) (N. viridula (L.) were collected from two different areas, Breeza $\left(31^{\circ} 14^{\prime} 54^{\prime \prime} \mathrm{N} 150^{\circ} 28^{\prime} 02^{\prime \prime} \mathrm{E}\right)$ and Grafton $\left(29^{\circ} 41^{\prime} 34^{\prime \prime} \mathrm{N}\right.$ $\left.152^{\circ} 55^{\prime} 56^{\prime \prime} \mathrm{E}\right)$, New South Wales, Australia. Breeza represents a dry climate $(621 \mathrm{~mm}$ annual average rainfall) compared to Grafton $(1073 \mathrm{~mm})$. Grafton is also more humid with average annual 3 pm relative humidity of $53 \%$ compared to $46 \%$ at Breeza. Average annual maximum temperature is similar at both sites $\left(26^{\circ} \mathrm{C}\right)$ but minimum temperature is higher at Grafton $\left(13.7^{\circ} \mathrm{C}\right)$ compared to Breeza $\left(10.9^{\circ} \mathrm{C}\right)(\mathrm{BOM}, 2011)$.

Adults were collected on soybean crops by sweep net or beat sheet and placed into plastic containers (64 mm deep and $118 \mathrm{~mm}$ in diameter). Air supply was provided by cutting a small hole ( $65 \mathrm{~mm}$ of diameter) in the lid and fitted with mosquito netting. The GVB were provided with fresh green fruit of legume plus water via a cotton wick. All field-fresh GVB samples were returned to the laboratory culture room and maintained at a temperature of $25 \pm 1^{\circ} \mathrm{C}$, under photoperiodic conditions of light:dark (L:D) $14: 10 \mathrm{~h}$ and at $60 \pm 10 \%$ relative humidity. Adult GVB were kept in a cage with 100-150 GVB per cage and fed with fresh green beans (Phaseolus vulgaris) plus water supplied via a cotton wick. For acclimation groups, cages were randomly assigned to incubators with temperature regulated at either $10,20,30$, or $35^{\circ} \mathrm{C}$ for 7 days with photoperiodic conditions, L:D 14:10 h, before being tested for the effects of acclimated treatments on LTs and CTL. After completion of the acclimation period, the 10-14 day old GVB adults (proportion of male and females approximately 1:1) were taken from the cages and tested immediately. For logistical reasons, the acclimation treatments of two populations, from Breeza and Grafton were tested at the same time. Rearing, acclimation, and experiments were conducted in the Insect Ecology Laboratory of the Zoology Department at the University of New England.

\section{LETHAL TEMPERATURE OF GVB AND EFFECTS OF ACCLIMATION TEMPERATURE ON SURVIVAL LETHAL TEMPERATURE}

GVB from both Grafton and Breeza were tested to determine whether the LT differed between populations. The lethal (discriminating) temperature was defined as the temperature at which approximately $20 \%$ of insects survived for $24 \mathrm{~h}$ after a direct plunge to the stress temperature for $2 \mathrm{~h}$ (Powell and Bale, 2004; Terblanche et al., 2005b). A group of five GVB adults was placed into a $35 \mathrm{ml}$ vial with enclosing cap. Each treatment temperature was replicated four times. The vials were then placed into double plastic bags with a vial in contact with the thermocouple temperature (Squirrel Data Logger, Grant 2020 series). Thereafter, the plastic bags were submerged in liquid (1:1 water:glycol) in a water bath (Grant R4, Grant instruments, Cambridge, UK) for $2 \mathrm{~h}$ set to six temperatures between 36 and $46^{\circ} \mathrm{C}$ for high temperature stress and set to six temperatures between 0 and $-12^{\circ} \mathrm{C}$ for low temperature stress. The temperature of the thermocouple was recorded every $30 \mathrm{~min}$. It was assumed that the body temperatures of GVB were equivalent to the inside vial temperature. After $2 \mathrm{~h}$ treatment, the vials were removed from the water bath and retained in the culture room for $24 \mathrm{~h}$ for survival assessment. The GVB were classified as alive if they displayed a righting response and were capable of coordinated walking; and as dead if they were unable to return to their normal upright position or maintained muscle function was lost during the decline in temperature.

The effects of acclimation on survival LT were determined for acclimated individuals in different temperature regimes. Adult GVB were maintained in incubators at $10,20,30$, and $35^{\circ} \mathrm{C}$ for 7 days before being tested. Similar methods to those described above were used. A group of five individuals was placed into a vial with a volume of $35 \mathrm{ml}$ and enclosing cap. Each treatment temperature was replicated four times. The vials were then placed into double plastic bags with a vial connected to thermocouple temperature recorders. Thereafter, the plastic bags were submerged in a water bath for $2 \mathrm{~h}$. Thermocouple temperature was recorded every $30 \mathrm{~min}$. After $2 \mathrm{~h}$ of treatment, all the vials were removed from plastic bags and placed in the culture room for $24 \mathrm{~h}$ to assess survival and mortality of the GVB.

\section{CRITICAL THERMAL LIMITS (CTL) AND THE EFFECTS OF ACCLIMATION TEMPERATURE ON CTL}

Upper and lower thermal limits can be measured in different ways such as mortality assays and estimates of knockdown temperature (Hoffmann et al., 1997; Berrigan and Hoffmann, 1998). Knockdown temperature is the upper or lower temperature at which the individuals lose the ability to cling to an inclined surface (Gilchrist and Huey, 1999). Knockdown temperatures were assessed because they are thought to be more ecologically relevant to mobile stages, such as insect adults compared to mortality assays (Hoffmann et al., 1997; Sørensen and Loeschcke, 2001). To determine lower and upper knockdown temperatures, CTL were used. For the low temperature tolerance, critical thermal minima $\left(\mathrm{CT}_{\text {Min }}\right)$ were used. These were identified as the onset of chill coma. For the high temperature tolerance, critical thermal maxima $\left(\mathrm{CT}_{\mathrm{Max}}\right)$ were used and identified as the onset of heat stupor (Klok and Chown, 1997, 1998).

For this experiment, the methods used were similar to those described by Klok and Chown (2003) and Terblanche et al. (2005b). A group of $10 \mathrm{GVB}$ was assessed for each treatment, and wherever possible three $\mathrm{CT}_{\text {Min }}$ and $\mathrm{CT}_{\text {Max }}$ trials were conducted as replications for each acclimation treatment and using the 
culture-room GVB as control treatment. Ten GVB were placed individually into plastic vials. A copper-constantan thermocouple gauge was placed inside one of the vials to measure vial ambient temperature. It was assumed that the body temperatures of GVB were similar to the temperature inside the vial. The vials were submerged in a water bath which contained distilled water and glycol in a proportion of $1: 1$. For $\mathrm{CT}_{\text {MinOnset, }}$ the water bath temperature was allowed to stabilize for $15 \mathrm{~min}$ at $10^{\circ} \mathrm{C}$ after which it was lowered at $0.25^{\circ} \mathrm{C} \mathrm{min}^{-1}$ until the onset of chill coma was observed in all individuals. The onset of chill coma was considered as the temperature at which a GVB was unable to right itself. Thereafter, the bath temperature was lowered $0.5^{\circ} \mathrm{C}$ below the last

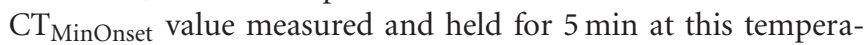
ture before being raised again at $0.25^{\circ} \mathrm{C} \mathrm{min}^{-1}$, the water bath was programmed to increase temperature at $0.25^{\circ} \mathrm{C} \mathrm{min}{ }^{-1}$. As the temperature increased, the behavior of GVB was monitored again for the recovery from cold stupor. The critical thermal minimum recovery $\left(\mathrm{CT}_{\text {MinRecovery }}\right)$ was observed until all GVB had regained full motor coordination. The critical thermal maximum $\left(\mathrm{CT}_{\mathrm{Max}}\right)$ of individuals was recorded as the onset of muscle spasms during increasing temperature (Lutterschmidt and Hutchison, 1997; Terblanche et al., 2005b). This procedure was continued until the $\mathrm{CT}_{\mathrm{Max}}$ was reached for all individuals.

\section{DATA ANALYSIS}

The data sets of the LTs were assessed for probability of survival by using Predictive Analytics SoftWare (PASW) Statistics 18 (SPSS Inc) and curves of LT were generated using the SigmaPlot for Windows 8.02 program (SPSS Inc). The data set of knock down temperatures was examined using a 2-way interaction analysis of variance with IRRISTAT for Windows 5.0 (International Rice Research Institute, IRRI). Data means were compared using least significant differences at the level of 5\% (5\% LSD).

\section{RESULTS}

\section{LETHAL TEMPERATURE OF GVB AND EFFECTS OF ACCLIMATION TEMPERATURE ON SURVIVAL LETHAL TEMPERATURE}

The upper LT of Grafton GVB $\left(40.4^{\circ} \mathrm{C}\right)$ for the high temperature exposure was similar to those from Breeza $\left(40.2^{\circ} \mathrm{C}\right.$ ) (Figures 1A and B) with a mean upper LT of $40.3^{\circ} \mathrm{C}$. For the low temperature exposure, lower LT for Grafton and Breeza GVB did not differ $\left(-8.0^{\circ} \mathrm{C}\right)$ (Figures $\mathbf{1 C}$ and $\left.\mathbf{D}\right)$.

The survival rate of both Breeza and Grafton GVB populations increased by $10-30 \%$ when acclimated to higher temperatures of $30^{\circ} \mathrm{C}$ and $35^{\circ} \mathrm{C}$ for 7 days compared to $\mathrm{GVB}$ maintained at the culture room temperature of $25^{\circ} \mathrm{C}\left(20 \%\right.$ survival at $\left.40.3^{\circ} \mathrm{C}\right)$ (Figures 2A and B). However, when Breeza and Grafton GVB populations were acclimated at the low temperatures of 10 and $15^{\circ} \mathrm{C}$ for 7 days, survival did not improve compared to the $25^{\circ} \mathrm{C}$ control $\left(20 \%\right.$ survival at $\left.-8^{\circ} \mathrm{C}\right)$. The survival of Breeza and Grafton GVB acclimated at $10^{\circ} \mathrm{C}$ and $15^{\circ} \mathrm{C}$ decreased about $10 \%$ compared to lower LT for control GVB (Figures 2C and D).

\section{CRITICAL THERMAL LIMITS (CTL) AND THE EFFECTS OF ACCLIMATION TEMPERATURE ON CTL}

The $25^{\circ} \mathrm{C}$ reared $\mathrm{GVB}$ control adults had a mean $\mathrm{CT}_{\text {MinOnset }}$ (cold stupor) of $1.3^{\circ} \mathrm{C}$ and a mean $\mathrm{CT}_{\mathrm{Max}}$ (heat coma) of $45.9^{\circ} \mathrm{C}$. $\mathrm{CT}_{\text {Max }}$ did not differ between the $30^{\circ} \mathrm{C}$-acclimated, $35^{\circ} \mathrm{C}$ acclimated and $25^{\circ} \mathrm{C}$ control groups (Table 1). However, $\mathrm{CT}_{\mathrm{Max}}$ of $20^{\circ} \mathrm{C}$-acclimated and $10^{\circ} \mathrm{C}$-acclimated GVB were significantly different by $0.9^{\circ} \mathrm{C}$ and $1.1^{\circ} \mathrm{C}$ compared to the control $(P<$ 0.0001). The corresponding differences for the $30^{\circ} \mathrm{C}$-acclimated group were $1.2^{\circ} \mathrm{C}$ and $1.4^{\circ} \mathrm{C}$ and $1.1^{\circ} \mathrm{C}$ and $1.3^{\circ} \mathrm{C}$ for the $35^{\circ} \mathrm{C}$-acclimated group (Table $\mathbf{1}$ ).

$\mathrm{CT}_{\text {MinOnset }}$ of the $25^{\circ} \mathrm{C}$ reared (control) and $20^{\circ} \mathrm{C}$-acclimated GVB did not differ significantly, but were significantly lower than the $\mathrm{CT}_{\text {MinOnset }}$ for $\mathrm{GVB}$ acclimated to 30 and $35^{\circ} \mathrm{C}$. $\mathrm{CT}_{\text {MinOnset }}$ of $10^{\circ} \mathrm{C}$-acclimated GVB was significantly lower $\left(1.1^{\circ} \mathrm{C}\right)$ than that of the controls, $30^{\circ} \mathrm{C}$-acclimated GVB $\left(2.2^{\circ} \mathrm{C}\right)$, and $35^{\circ} \mathrm{C}$-acclimated $\operatorname{GVB}\left(4.3^{\circ} \mathrm{C}\right) . \mathrm{CT}_{\text {MinOnset }}$ of $10^{\circ} \mathrm{C}$-acclimated and $20^{\circ} \mathrm{C}$-acclimate GVB did not differ significantly (Table 1). $\mathrm{CT}_{\text {MinRecovery }}$ tended to be higher in GVB exposed to the higher temperatures, but the patterns were unclear as they were exposed to lower treatment temperature compared to the $25^{\circ} \mathrm{C}$ control (Table 1). $\mathrm{CT}_{\text {MinRecovery }}$ of $30^{\circ} \mathrm{C}$-acclimated and $35^{\circ} \mathrm{C}$-acclimated GVB were significantly higher by $2.5^{\circ} \mathrm{C}$ and $5.1^{\circ} \mathrm{C}$ respectively compared to those of $25^{\circ} \mathrm{C}$ controls (Table 1). Overall, $\mathrm{CT}_{\text {Max }}$ varied by about $1^{\circ} \mathrm{C}$ over the treatment temperatures, whereas variation was slightly higher for $\mathrm{CT}_{\text {MinOnset }}$.

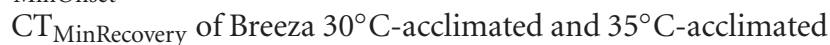
GVB was significantly higher than the corresponding data from Grafton GVB (1.4 and $2.1^{\circ} \mathrm{C}$, respectively). CT MinRecovery of other acclimated temperatures did not differ between Breeza and Grafton (Table 2) and $\mathrm{CT}_{\mathrm{Max}}$ and $\mathrm{CT}_{\text {MinOnset }}$ of Breeza and Grafton GVB did not differ across acclimated temperatures (Table 2).

\section{DISCUSSION}

LT (set at 20\% survival) is a method that can be used to describe the survival of GVB under unpredictable stress or extreme temperatures that are common within the insect's natural thermal habitat. LT has been shown to be an important measure of survival for a variety of other insect species and provides an indication of ability to survive unexpected and potentially lethal short term declines in temperature (Lee et al., 1987; Kelty and Lee, 1999; Terblanche et al., 2005b). LT of Breeza and Grafton GVB for the high temperature range averaged $40.3^{\circ} \mathrm{C}\left(40.2^{\circ} \mathrm{C}\right.$ for Breeza and $40.4^{\circ} \mathrm{C}$ for Grafton) and for the low temperatures it was $-8.0^{\circ} \mathrm{C}$ for both populations. These results might be an indication that the climatic differences between Breeza and Grafton were insufficient to affect LTs of GVB. Breeza represents a dry inland climate (621 $\mathrm{mm}$ annual average rainfall) compared to coastal Grafton (1073). Grafton is also more humid with an average annual 3 pm relative humidity of $53 \%$ compared to $46 \%$ at Breeza (Gunnedah). Though, the average annual maximum temperature is similar at both sites $\left(26^{\circ} \mathrm{C}\right)$, the average minimum temperature is higher at Grafton $\left(13.7^{\circ} \mathrm{C}\right)$ compared to Breeza $\left(10.9^{\circ} \mathrm{C}\right)$ (BOM, 2011). The small variation of temperature between these two habitats did not result in significant LT effects between GVB populations. Moreover, after collection of GVB from both locations, the insects were maintained in the same culture room under the same climatic conditions: temperature of $25^{\circ} \mathrm{C}$ and relative humidity of $60 \%$ for 7 days. Acclimation for 7 days at 10 and $15^{\circ} \mathrm{C}$ decreased survival of GVB by $\sim 10 \%$ (range 10-20\%) compared 


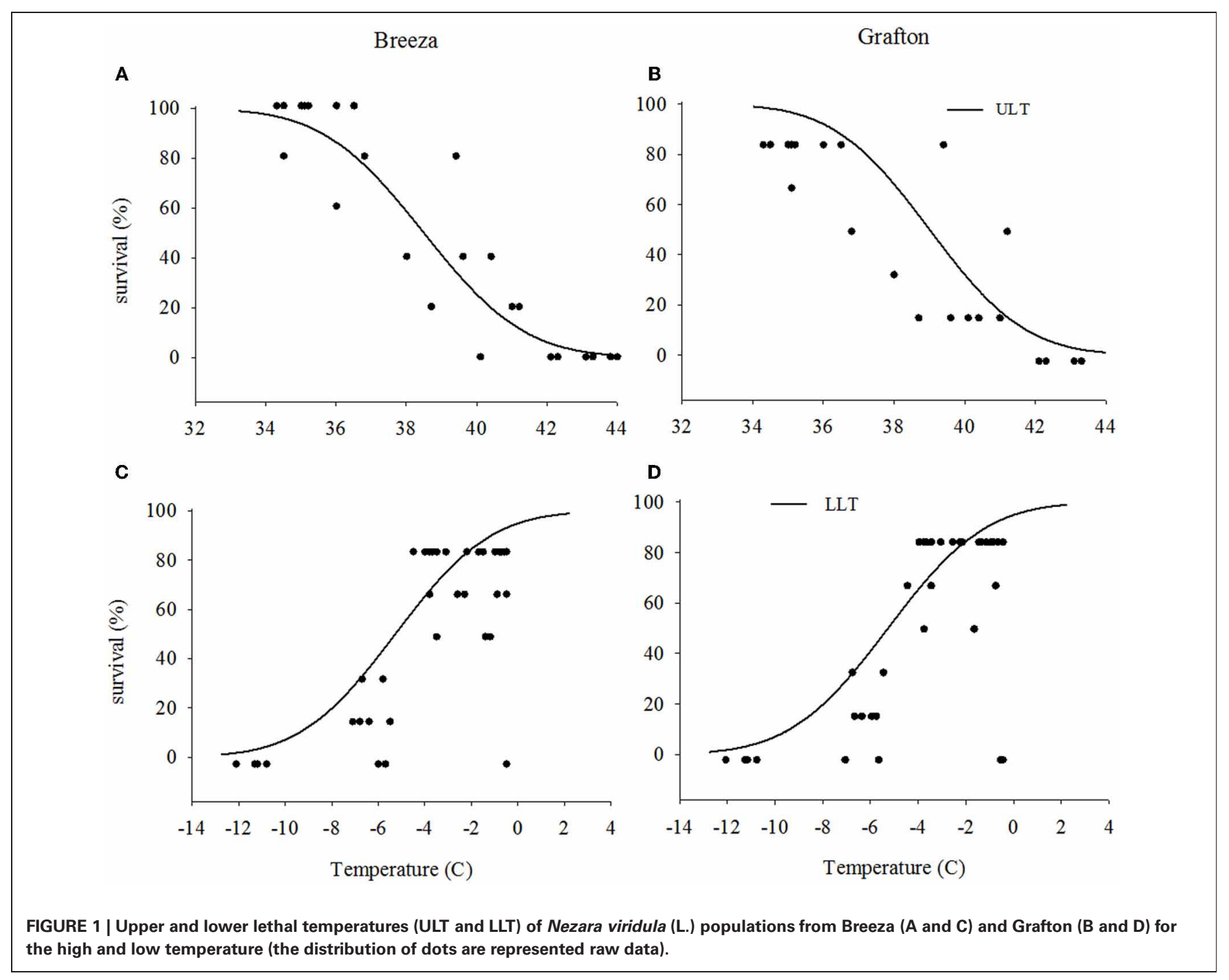

to non-acclimatised survival of LT (Figures 2C and D). Previous studies on other insects suggest that acclimation for longer times than the period required to induce maximum cold hardening resulted in slight decreases in survival with every extra hour of acclimation, indicating that extended exposure to low temperatures increases mortality (Powell and Bale, 2004). However, acclimation at $0^{\circ} \mathrm{C}$ for two and $3 \mathrm{~h}$ for nymphs and adults of the grain aphid, Sitobion avenae (Homoptera: Aphididae), respectively increased nymphal survival from 18 to $83 \%$ and adult survival from 16 to $68 \%$ compared with nymphs and adults exposed directly to the LT (Powell and Bale, 2004, 2005). In the present experiments, however, when GVB were acclimated at nonlethal higher temperatures of 30 and $35^{\circ} \mathrm{C}$, LT survival increased by up to $50 \%$ (Figures $2 \mathbf{A}$ and $\mathbf{B}$ ). These results suggested that Breeza and Grafton GVB were tolerant to warmer than average temperatures and they would adapt to the temperature extremes in the environment for survival.

Chen et al. (1990) revealed that adaptations to temperature stress differ between tropical and temperate flesh flies (Diptera: Sarcophagidae). While sarcophagids from both geographical areas share a mechanism for rapidly increasing heat tolerance only temperate zone sarcophagids appeared capable of responding rapidly to cold stress. One consistent parameter to change with thermal acclimation in ectotherms is the ability to withstand extreme temperature, warmer acclimated animal will have a higher tolerance to high temperature exposure than the same animal when cold acclimated (Cossins and Bowler, 1987). It is important to note that the daily maximum and minimum temperature in 2010 at Breeza and Grafton did not exceed the upper and lower LT of GVB. At Breeza in 2011 there were 2 days (26-27 January 2011), which the daily maximum temperature exceeded the upper LT of GVB. However, the daily maximum temperature in Grafton did not exceed the ULT of GVB. The minimum temperature in 2010 and 2011 did not exceed the lower LT neither locations (BOM, 2012). In Drosophila resistance to high temperature has been much studied as a trait subject to selection (Levins, 1969; Quintana and Prevosti, 1990; Huey et al., 1992; Krebs and Loeschcke, 1997).

Insects can increase resistance to heat or cold stress when exposed to non-lethal conditions prior to stress; these plastic 


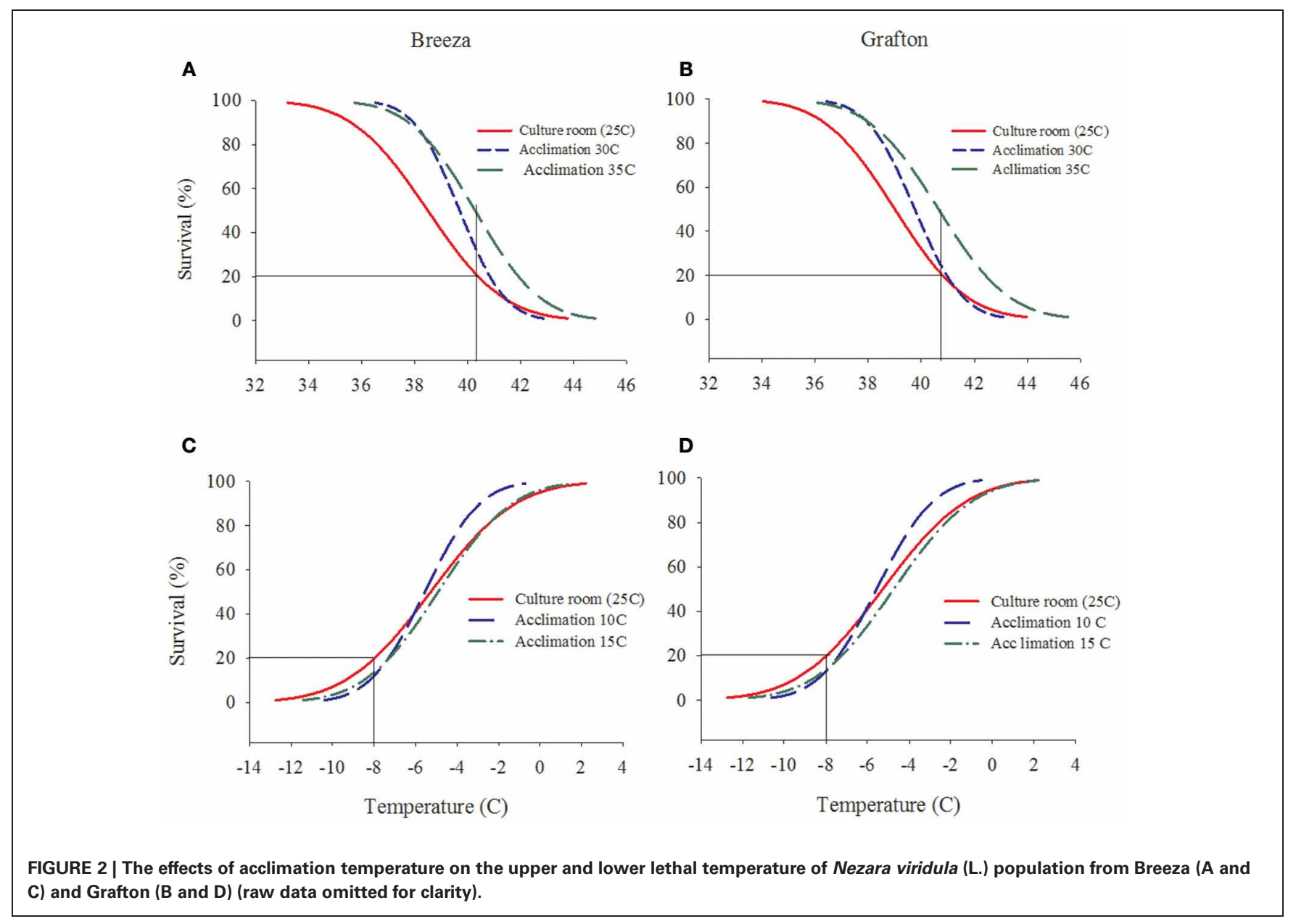

Table 1 | Physiological variation of Nezara viridula (L.) in culture room and laboratory temperature acclimation.

\begin{tabular}{|c|c|c|c|c|c|c|}
\hline Physiological variable $\left({ }^{\circ} \mathrm{C}\right)$ & \multicolumn{5}{|c|}{ Acclimation temperature $\left({ }^{\circ} \mathrm{C}\right)$} & $P$ \\
\hline $\mathrm{CT}_{\operatorname{Max}}$ & $44.8 \pm 2.0^{b}$ & $45.0 \pm 1.0^{b}$ & $45.9 \pm 0.9^{a}$ & $46.2 \pm 1.0^{\mathrm{a}}$ & $46.1 \pm 1.6^{a}$ & $<0.0001$ \\
\hline $\mathrm{CT}_{\text {MinOnset }}$ & $0.2 \pm 2.0^{d}$ & $0.7 \pm 2.1^{\mathrm{cd}}$ & $1.3 \pm 2.1^{\mathrm{c}}$ & $2.4 \pm 2.7^{b}$ & $4.5 \pm 3.0^{\mathrm{a}}$ & $<0.0001$ \\
\hline $\mathrm{CT}_{\text {MinRecovery }}$ & $17.1 \pm 2.0^{\mathrm{cd}}$ & $17.9 \pm 2.4^{c}$ & $16.4 \pm 1.7^{d}$ & $18.9 \pm 2.9^{b}$ & $21.5 \pm 3.4^{\mathrm{a}}$ & $<0.0001$ \\
\hline
\end{tabular}

$n$ - number of insects tested, "**insects from culture, $25^{\circ} \mathrm{C}$.

Mean \pm standard deviation (SD), Means followed by same superscript letters in the same row are not significantly different at $p=0.05$ using IRRISTAT program for Windows 5.0. Means were compared by the method of least significant differences at $5 \%$ level (5\% LSD).

responses are normally described only in terms of immediate effects on mortality (Rako and Hoffmann, 2006). From the present GVB data, acclimation at temperatures lower than the $25^{\circ} \mathrm{C}$ control had a strong, significant and negative impact on the $\mathrm{CT}_{\mathrm{Max}}$. Overall, the mean temperature for thermal tolerance $\left(\mathrm{CT}_{\text {Max }}-\mathrm{CT}_{\text {MinOnset }}\right.$ ) was $43.8^{\circ} \mathrm{C}$ (ranging from 41.6 to $44.6^{\circ} \mathrm{C}$ depending on the acclimation temperature). At Breeza and Grafton, the daily maximum temperature in 2010 was below $40^{\circ} \mathrm{C}$ as mentioned earlier. However, based on long-term climate records, the highest daily temperatures in the Breeza area have ranged from 43.3 to $48.7^{\circ} \mathrm{C}$ and at up to $43.8^{\circ} \mathrm{C}$ at Grafton
(BOM, 2012). These extreme temperatures exceeded the thermal tolerance of GVB and may have affected the mortality rate of GVB at both locations. In NSW, summer temperature is expected to rise by up to $2.3^{\circ} \mathrm{C}$ by 2030 as a result of climate change (CSIRO, 2006). It is therefore expected that GVB will be exposed to lethal high temperature extremes more frequently in the future, particularly at Breeza.

Temperate insects have a consistent pattern of thermal responses (Chen et al., 1990; Chown, 2001; Klok and Chown, 2003). In GVB, $C_{\text {Max }}$ declined significantly with low temperature acclimation and increased with high temperature 
Table 2 | Interactions of location and physiological variation of Nezara viridula (L.) in culture room and laboratory temperature acclimated.

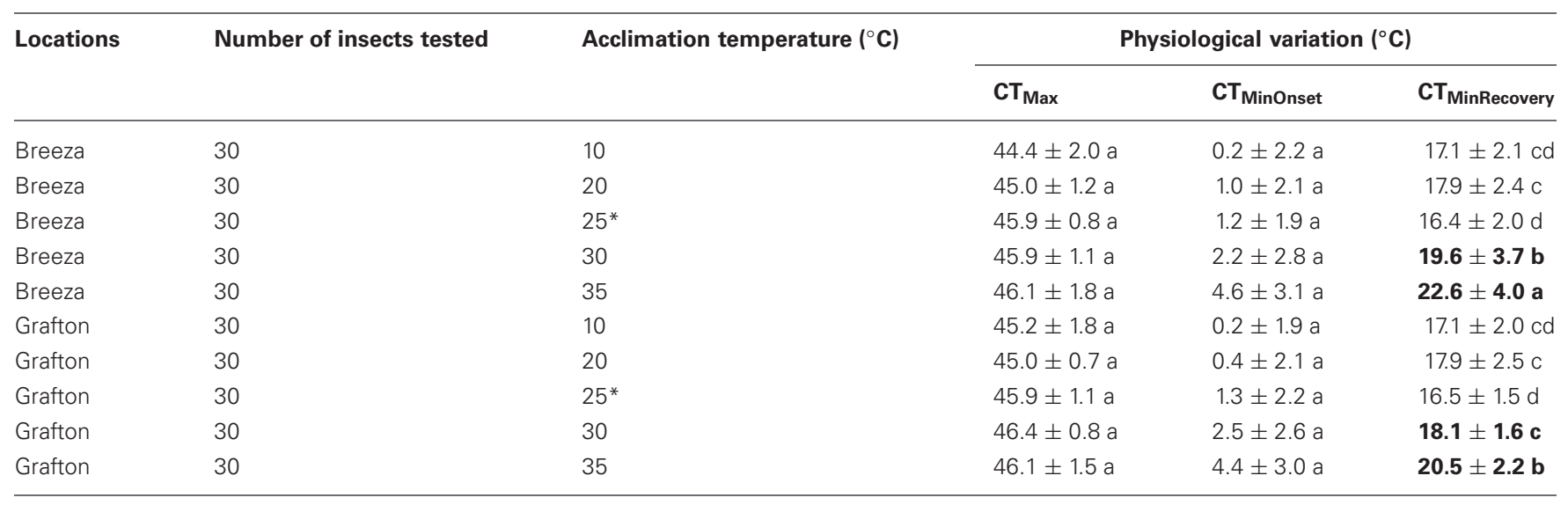

Bolded results are significant differences between locations within the same acclimation temperature.

${ }^{*}$ Insects from culture, $25^{\circ} \mathrm{C}$.

Mean \pm standard deviation (SD), Means followed by same letters in the same column are not significantly different at $p=0.05$ using IRRISTAT program for Windows 5.0. Means were compared by the method of least significant differences at $5 \%$ level (5\% LSD).

acclimation, but did not differ significantly compared to the constant $25^{\circ} \mathrm{C}$ control (Table 1). The difference in $\mathrm{CT}_{\text {Max }}$ between all the treatments was more than $1^{\circ} \mathrm{C}$, whereas the $\mathrm{CT}_{\text {MinOnset }}$ temperatures were significantly affected by acclimation, spanning a range of $1.5^{\circ} \mathrm{C}$ over an acclimation range of $10-35^{\circ} \mathrm{C}$. These results are broadly consistent with other insect observations that, upper and lower CTL are typically decoupled, with lower critical limits showing great variation and a more plastic response to acclimation than upper limits (Chown, 2001; Kimura, 2004; Hoffmann et al., 2005; Terblanche et al., 2005b).

$\mathrm{CT}_{\mathrm{Max}}$ and $\mathrm{CT}_{\text {MinOnset }}$ did not differ between populations of Breeza and Grafton GVB. Grafton is also more humid with average annual $3 \mathrm{pm}$ relative humidity of $53 \%$ compared to $46 \%$ at Breeza. Average annual maximum temperature is similar at both sites $\left(26^{\circ} \mathrm{C}\right)$ but minimum temperature is higher at Grafton $\left(13.7^{\circ} \mathrm{C}\right)$ compared to Breeza $\left(10.9^{\circ} \mathrm{C}\right)(\mathrm{BOM}, 2011)$. There is evidence from Global observations gathered since 1950 of change in some climate extremes. Global-scale trends in extremes for temperature are considered to be reliable but regional-scale trends could be less reliable depending on the geographical uniformity (IPCC, 2012). Based on historical temperature records from 1950 (BOM, 2012), there have been 62 days exceeding $40^{\circ} \mathrm{C}$ at Breeza ( 1.0 days per year). However since 1990, there have been 35 days exceeding $40^{\circ} \mathrm{C}$ at Breeza (1.9 days per year) (Figure 3).

In comparison, there are fewer high temperature extremes at Grafton. Since 1950 , there have been 30 days exceeding $40^{\circ} \mathrm{C}$ at Grafton ( 0.5 days per year). Since 1990, there have been 19 days exceeding $40^{\circ} \mathrm{C}$ at Grafton ( 1.0 days per year).

The occurrence of days exceeding $40^{\circ} \mathrm{C}$ at both Breeza and Grafton has been increasing since 1990 (Figure 3). However, records at Breeza show that it has not followed the global trend for increasing temperatures since the 1890s where, at Breeza, $65 \%$ of the days exceeding $40^{\circ} \mathrm{C}$ were recorded between 1899 and 1950 with 6.6 days per year exceeding $40^{\circ} \mathrm{C}$ during this period. Therefore regional-scale climate trends appear to be operating at Breeza.

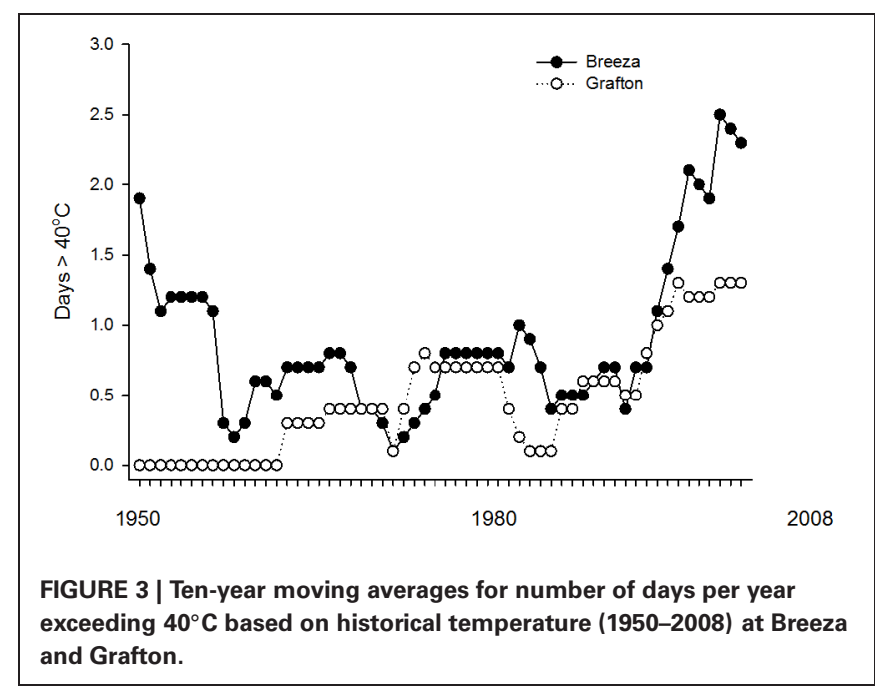

Overall, Breeza appears to be a less hospitable place for $N$. viridula than Grafton with respect to temperatures exceeding $40^{\circ} \mathrm{C}$. If the current trend for increasing frequency of temperatures exceeding $40^{\circ} \mathrm{C}$ at Breeza continues, conditions could become unsuitable for N. viridula, especially if they return to the levels experienced between 1899 and 1950. The number of days per year below $-8^{\circ} \mathrm{C}$ has not occurred at either location.

In summary, data presented here suggest that the LT did not differ between two populations of GVB collected at Breeza and Grafton. LTs for GVB were shown to be $40.3^{\circ} \mathrm{C}$ and $-8.0^{\circ} \mathrm{C}$ for high and low temperatures, respectively. N. viridula responded more strongly to extreme hot temperature, survival was increased at the upper LT when GVB were acclimated at 30 or $35^{\circ} \mathrm{C}$ for 7 days. In contrast, survival of GVB decreased for lower LT when acclimated at 20 or $10^{\circ} \mathrm{C}$. Therefore, when knock-down of GVB under extreme temperature was investigated, $\mathrm{CT}_{\mathrm{Max}}$ of 
GVB did not differ between those maintained at constant $25^{\circ} \mathrm{C}$ control and high temperature acclimated $\left(30\right.$ or $\left.35^{\circ} \mathrm{C}\right)$ groups. $\mathrm{CT}_{\text {MinOnset }}$ of $10^{\circ} \mathrm{C}$-acclimated GVB was significantly lower (by $1.1^{\circ} \mathrm{C}$ ) than that of GVB from the $25^{\circ} \mathrm{C}$ constant temperature control. These data suggest that GVB species are more tolerant of low temperature when acclimated at $10^{\circ} \mathrm{C}$.

Much remains to be learned about the mechanistic basis and ecological and physiological relevance of LT for N. viridula. Further study is required to determine LT of nymphal stages, GVB response to recovery time after exposure to extreme temperature and rapid cold hardening $(\mathrm{RCH}) . \mathrm{RCH}$ in insects is detected as an increase in survival at a LT following a brief period of acclimation (1-3 h), at low temperature (typically $0^{\circ} \mathrm{C}$ ) (Powell and Bale, 2005). Finally, a better understanding of desiccation resistance in nymphs and adult GVB would be helpful in predicting response to climate change.

\section{ACKNOWLEDGMENTS}

Financial support was given to Pol Chanthy by Australian Centre for International Agricultural Research (ACIAR) who provided a John Allwright Fellowship (JAF) Award through Australian Agency for International Development (AusAID), and UNE.

\section{REFERENCES}

Ayrinhac, A., Debat, V., Gibert, P., Kister, A.-G., Legout, H., Moreteau, B., et al. (2004). Cold adaptation in geographical populations of Drosophila melanogaster: phenotypic plasticity is more important than genetic variability. Funct. Ecol. $18,700-706$.

Berrigan, D., and Hoffmann, A. A. (1998). Correlations between measures of heat resistance and acclimation in two species of Drosophila and their hybrids. Biol. J. Linn. Soc. 64, 449-462.

BOM. (2011). Climate Data Online, Climate Statistics for Australian Locations (Monthy Climate Statistic). Bureau of Meteorology, Australian Government. Available online at: http://www.bom.gov.au/climate/ climate/averages/tables/ [Accessed 16 March 2011].

BOM. (2012). Climate Data Online, Climate Statistics for Australian Locations (Monthy Climate Statistic). Bureau of Meteorology, Australian Government. (Online). [Accessed 13 August 2012].

Carrillo, M. A., Cannon, C. A., Wilcke, W. F., Morey, R. V., Kaliyan, N., and Hutchison, W. D. (2005). Relationship between supercooling point and mortality at low temperatures in indianmael moth (Lepidoptera: Pyralidae). J. Econ. Entomol. 98, 618-625.

Chen, C.-P., Lee, R. E., and Denlinger, D. L. (1990). A comparison of the responses of tropical and temperate flies (Diptera: Sarcophagidae) to cold and heat stress. J. Comp. Physiol. B 160, 543-547.

Chown, S. L. (2001). Physiological variation in insects: hierarchical levels and implications. J. Insect Physiol. 47, 649-660.

Chown, S. L., Addo-Bediako, A., and Gaston, K. J. (2002). Physiological variation in insects: large-scale patterns and their implications. Comp.
Biochem. Physiol. B Biochem. Mol. Biol. 131, 587-602.

Cossins, A. R., and Bowler, K. (1987). Temperature Biology of Animals. London: Chapman and Hall.

CSIRO. (2006). Climate Change. Available online at: http:// www.dar.csiro.au/information/clim atechange.html

Czajka, M. C., and Lee, J. R. E. (1990). A rapid cold-hardening response protecting against cold shock injury in Drosophila melanogaster. J. Exp. Biol. 148, 245-254.

Gibbs, A. G., Perkins, M. C., and Markow, T. A. (2003). No place to hide: microclimates of Sonoran Desert Drosophila. J. Therm. Biol. 28, 353-362.

Gilchrist, G. W., and Huey, R. B. (1999). The direct response of Drosophila melanogaster to selection on knockdown temperature. Heredity 83, 15-29.

Graham, L., Walker, V., and Davies, P. (2000). Developmental and environmental regulation of antifreeze proteins in the mealworm beetle Tenebrio molitor. Eur. J. Biochem. 267, 6452-6468.

Hoffmann, A. A., Dagher, H., Hercus, M., and Berrigan, D. (1997). Comparing different measures of heat resistance in selected lines of Drosophila melanogaster. J. Insect Physiol. 43, 393-405.

Hoffmann, A. A., Shirriffs, J., and Scott, M. (2005). Relative importance of plastic vs genetic factors in adaptive differentiation: geographical variation for stress resistance in Drosophila melanogaster from eastern Australia. Funct. Ecol. 19, 222-227.

Huey, R. B., Crill, W. D., Kingsolver, J. G., and Weber, K. E. (1992). A method for rapid measurement of heat or cold resistance of small insects. Funct. Ecol. 6, 489-494.

IPCC. (2012). "Managing the risks of extreme events and disasters to advance climate change adaptation," in A Special Report of
Working Groups I and II of the Intergovernmental Panel on Climate Change, eds C. B. Field, V. Barros, T. F. Stocker, D. Qin, D. J. Dokken, K. L. Ebi, et al. (Cambridge, UK: Cambridge University Press), 1-20.

Kelty, J. D., and Lee, R. E. (1999). Induction of rapid cold hardening by cooling at ecologically relevant rates in Drosophila melanogaster. J. Insect Physiol. 45, 719-726.

Kimura, M. T. (2004). Cold and heat tolerance of drosophilid flies with reference to their latitudinal distributions. Oecologia 140, 442-449.

Kiritani, K. (2006). Predicting impact of global warming on population dynamics and distribution of arthropods in Japan. Popul. Ecol. 48, 5-12.

Kiritani, K. (2007). The impact of global warming and land-use change on the pest status of rice and fruit bugs (Heteroptera) in Japan. Glob. Change Biol. 13, 1586-1595.

Klok, C. J., and Chown, S. L. (1997). Critical thermal limits, temperature tolerance and water balance of subantarctic caterpillar, Pringleophaga marioni (Lepidoptera: Tineidae). J. Insect Physiol. 43, 685-694.

Klok, C. J., and Chown, S. L. (1998). Interactions between desiccation resistance, host-plant contact and the thermal biology of a leaf-dwelling sub-antarctic caterpillar, Embryonopsis halticella (Lepidoptera: Yponomeutidae). J. Insect Physiol. 44, 615-628.

Klok, C. J., and Chown, S. L. (2003). Resistance to temperature extremes in sub-Antarctic weevils: interspecific variation, population differentiation and acclimation. Biol. J. Linn. Soc. 78, 401-414.

Krebs, R. A., and Loeschcke, V. (1997). Estimating heritability in a threshold trait: heat-shock tolerance in Drosophila buzzatii. Heredity 79 , 252-259.
Lee, R. E., Chen, C.-P., and Denlinger, D. L. (1987). A rapid coldhardening process in insects. Science 238, 1415-1417.

Levins, R. (1969). Thermal acclimation and heat resistance in Drosophila species. Am. Nat. 103, 483-499.

Lutterschmidt, W. I., and Hutchison, V. H. (1997). The critical thermal maximum: history and critique. Can. J. Zool. 75, 1561.

Musolin, D. L., Fujisaki, K., and Numata, H. (2007). Photoperiodic control of diapause termination, colour change and postdiapause reproduction in the southern green stink bug, Nezara viridula. Physiol. Entomol. 32, 64-72.

Musolin, D. L., and Numata, H. (2003a). Photoperiodic and temperature control of diapause induction and colour change in the southern green stink bug, Nezara viridula. Physiol. Entomol. 28, 65-74.

Musolin, D. L., and Numata, H. (2003b). Timing of diapause induction and its life-history consequences in Nezara viridula: is it costly to ezpand the distribution range? Ecol. Entomol. 28, 694-703.

Musolin, D. L., Tsytsulina, K., and Ito, K. (2004). Photoperiodic and temperature control of reproductive diapause induction in the predatory bug Orius strigicollis (Heteroptera: Anthocoridae) and its implications for biological control. Biol. Control 31, 91-98.

Powell, S. J., and Bale, J. S. (2004). Cold shock injury and ecological costs of aphid cold hardening in the grain aphid Sitobion avenae (Hemiptera: Aphididae). J. Insect Physiol. 50, 277-284.

Powell, S. J., and Bale, J. S. (2005). Low temperature acclimated populations of the grain aphid Sitobion avenae retain ability to rapidly cold harden with enhanced fitness. J. Exp. Biol. 208, 2615-2620.

Quintana, A., and Prevosti, A. (1990). Genetic and environmental factors in the resistance of 
Drosophila subobscura adults to high temperature shock. Theor. Appl. Genet. 80, 847-851.

Rako, L., and Hoffmann, A. A. (2006). Complexity of the cold acclimation response in Drosophila melanogaster. J. Insect Physiol. 52, 94-104.

Salt, R. W. (1961). Principles of insect cold-hardeness. Ann. Rev. Euratomol. 6, 55-74.

Sørensen, J. G., and Loeschcke, V. (2001). Larval crowding in Drosophila melanogaster induces Hsp70 expression, and leads to increased adult longevity and adult thermal stress resistance. J. Insect Physiol. 47, 1301-1307.

Terblanche, J. S., Hoffmann, A. A., Mitchell, K. A., Rako, L., Le Roux, P. C., and Chown, S. L. (2011). Ecologically relevant measures of tolerance to potentially lethal temperaures. J. Exp. Biol. 214, 3713-3725.
Terblanche, J. S., Jaco Klok, C., and Chown, S. L. (2005a). Temperaturedependence of metabolic rate in Glossina morsitans morsitans (Diptera, Glossinidae) does not vary with gender, age, feeding, pregnancy or acclimation. J. Insect Physiol. 51, 861-870.

Terblanche, J. S., Sinclair, B. J., Jaco Klok, C., McFarlane, M. L., and Chown, S. L. (2005b). The effects of acclimation on thermal tolerance, desiccation resistance and metabolic rate in Chirodica chalcoptera (Coleoptera: Chrysomelidae). J. Insect Physiol. 51, 1013-1023.

Watson, M. J. O., and Hoffmann, A. A. (1996). Acclimation, cross-generation effects, and the response to selection for increased cold resistance in Drosophila. Evolution 50, 1182-1192.
Yukawa, J., and Kiritani, K. (1965). Polymorphism in the southern green stink bug. Pac. Insects 7 , 639-642.

Yukawa, J., Kiritani, K., Gyoutoku, N., Uechi, N., Yamaguchi, D., and Kamitani, S. (2007). Distribution range shift of two allied species, Nezara viridula and $N$. antennata (Hemiptera: Pentatomidae), in Japan, possibly due to global warming. Appl. Entomol. Zool. 42, 205-215.

Zachariassen, K. E. (1985). Physiology of cold tolerance in insects. Physiol. Rev. 65, 799-832.

Conflict of Interest Statement: The authors declare that the research was conducted in the absence of any commercial or financial relationships that could be construed as a potential conflict of interest.
Received: 26 October 2012; accepted: 24 November 2012; published online: 12 December 2012.

Citation: Chanthy $P$, Martin RJ, Gunning RV and Andrew NR (2012) The effects of thermal acclimation on lethal temperatures and critical thermal limits in the green vegetable bug, Nezara viridula (L.) (Hemiptera: Pentatomidae). Front. Physio. 3:465. doi: 10.3389/fphys.2012.00465

This article was submitted to Frontiers in Invertebrate Physiology, a specialty of Frontiers in Physiology.

Copyright (c) 2012 Chanthy, Martin, Gunning and Andrew. This is an openaccess article distributed under the terms of the Creative Commons Attribution License, which permits use, distribution and reproduction in other forums, provided the original authors and source are credited and subject to any copyright notices concerning any third-party graphics etc. 